3-1-1999

\title{
The Problem of Underqualified Teachers in American Secondary Schools
}

Richard Ingersoll

University of Pennsylvania, rmi@upenn.edu

Follow this and additional works at: https://repository.upenn.edu/gse_pubs

Part of the Elementary and Middle and Secondary Education Administration Commons

\section{Recommended Citation}

Ingersoll, R. (1999). The Problem of Underqualified Teachers in American Secondary Schools. Retrieved from https://repository.upenn.edu/gse_pubs/139

Reprinted from Educational Researcher, Volume 28, Issue 2, March 1999, pages 26-37.

The author asserts his right to include this material in ScholarlyCommons@Penn.

NOTE: At the time of publication, author Richard M. Ingersoll, was affiliated with the University of Georgia. Currently, October 2007, he is a faculty member in the Graduate School of Education at the University of Pennsylvania.

This paper is posted at ScholarlyCommons. https://repository.upenn.edu/gse_pubs/139

For more information, please contact repository@pobox.upenn.edu. 


\title{
The Problem of Underqualified Teachers in American Secondary Schools
}

\begin{abstract}
This article presents the results of a research project on the phenomenon of out-of-field teaching in American high schools - teachers teaching subjects for which they have little education or training. Over the past couple of years, the problem of out-of-field teaching has become a prominent topic in the realm of educational policy and reform, and the results of this research have been widely reported and commented on both by education policymakers and the national media. But unfortunately, out-of-field teaching is a problem that remains largely misunderstood. My research utilizes nationally representative data from the Schools and Staffing Survey, conducted by the National Center for Education Statistics. The purpose of this article is to summarize what my research has revealed about out-of-field teaching: how much of it goes on; to what extent it varies across different subjects, across different kinds of schools, and across different kinds of classrooms; and finally, the reasons for its prevalence in American schools. The data show that even using a minimal standard for qualified teachers - those holding a college minor in the fields in which they teach - the numbers of out-of-field teachers are striking. For example, a third of all secondary school teachers of mathematics have neither a major nor a minor in mathematics. My analyses have also shown that out-of-field teaching greatly varies across schools, teachers, and classrooms. The crucial question, however, and the source of great misunderstanding is why so many teachers are teaching subjects for which they have little background. I examine three widely believed explanations of out-of-field teaching - that out-of-field teaching is a result of either inadequate training on the part of teachers, inflexible teacher unions, or shortages of qualified teachers. My analysis shows that each of these views is seriously flawed. The article closes by offering an alternative explanation for outof-field teaching - one focused on the organizational structure of schools and the occupational conditions and characteristics of teaching.
\end{abstract}

\section{Disciplines}

Elementary and Middle and Secondary Education Administration

\section{Comments}

Reprinted from Educational Researcher, Volume 28, Issue 2, March 1999, pages 26-37.

The author asserts his right to include this material in ScholarlyCommons@Penn.

NOTE: At the time of publication, author Richard M. Ingersoll, was affiliated with the University of Georgia. Currently, October 2007, he is a faculty member in the Graduate School of Education at the University of Pennsylvania. 


\title{
The Problem of Underqualified Teachers in American Secondary Schools
}

\author{
RICHARD M. INGERSOLL
}

This article presents the results of a research project on the phenomenon of out-of-field teaching in American high schoolsteachers teaching subjects for which they have little education or training. Over the past couple of years, the problem of out-of-field teaching has become a prominent topic in the realm of educational policy and reform, and the results of this research have been widely reported and commented on both by education policymakers and the national media. But unfortunately, out-of-field teaching is a problem that remains largely misunderstood. My research utilizes nationally representative data from the Schools and Staffing Survey, conducted by the National Center for Education Statistics. The purpose of this article is to summarize what my research has revealed about out-of-field teaching: how much of it goes on; to what extent it varies across different subjects, across different kinds of schools, and across different kinds of classrooms; and finally, the reasons for its prevalence in American schools. The data show that even using a minimal standard for qualified teachers - those holding a college minor in the fields in which they teach-the numbers of out-of-field teachers are striking. For example, a third of all secondary school teachers of mathematics have neither a major nor a minor in mathematics. My analyses have also shown that out-of-field teaching greatly varies across schools, teachers, and classrooms. The crucial question, however, and the source of great misunderstanding is why so many teachers are teaching subjects for which they have little background. I examine three widely believed explanations of out-of-field teachingthat out-of-field teaching is a result of either inadequate training on the part of teachers, inflexible teacher unions, or shortages of qualified teachers. My analysis shows that each of these views is seriously flawed. The article closes by offering an alternative explanation for out-of-field teaching - one focused on the organizational structure of schools and the occupational conditions and characteristics of teaching.

Educational Researcher, Vol. 28, No. 2, pp. 26-37

$\mathbf{F}$ ew educational problems have received more attention in recent times than the failure to ensure that our nation's elementary and secondary classrooms are all staffed with qualified teachers. Over the past decade, dozens of studies, commissions, and national reports have bemoaned the qualifications and quality of our teachers. As a result, reformers in many states have pushed tougher teacher education and certification standards. Moreover, a whole host of initiatives and programs have sprung up that are designed to recruit new and talented candidates into teaching. Among these are programs designed to entice professionals into mid-career changes to teaching; alternative certification programs, whereby college graduates can postpone formal education training, obtain an emergency teaching certificate, and begin teaching immediately; and Peace Corps-like programs, such as Teach for America, which are designed to lure the "best and brightest" into understaffed schools. President Clinton has also joined the action: A key goal of the president's 10-point educational "Call to Action" is to ensure that our nation's elementary and secondary students are all taught by "talented and trained teachers." To this end, Clinton has, for example, proposed a major initiative to recruit and train thousands of new teachers to serve in low-income schools.

Concern with the quality and qualifications of teachers is neither unique nor surprising. Elementary and secondary schooling are mandatory in the U.S., and it is into the custody of teachers that children are legally placed for a significant portion of their lives. The quality of teachers and teaching is undoubtedly one of the most important factors shaping the learning and growth of students. Moreover, the largest single component of the cost of education in any country is teacher compensation.

However, although ensuring that our nation's classrooms are all staffed with qualified teachers is a perennially important issue in our schools, it is also among the least understood. Like many similarly worthwhile reforms, the array of recent efforts alone will not solve the problems of underqualified teachers and poor quality teaching in this country because they do not address some of their key causes.

One of the least recognized of these causes is the phenomenon known as out-of-field teaching-teachers assigned to teach subjects for which they have little training or education. Educators have, of course, long been aware of the existence of out-of-field teaching. James Conant called attention to the widespread "misuse of teachers" through out-of-field assignments in his landmark 1963 study The Education of American Teachers. Albert Shanker condemned out-of-field teaching as education's "dirty little secret" in a

RICHARD M. INGERSOLL is an assistant professor in the Department of Sociology, University of Georgia, Athens, GA 30602. He specializes in the sociology of organizations and occupations. 
1985 opinion piece in the New York Times. But an absence of accurate statistics on out-of-field teaching has kept this problem largely unrecognized, a situation remedied with the release, beginning in the early 1990s, of the Schools and Staffing Survey (SASS), a major new survey of the nation's elementary and secondary teachers conducted by the National Center for Education Statistics (NCES) of the U.S. Department of Education. ${ }^{1}$ Over the past five years, I have undertaken a research project that used this survey to determine how much out-of-field teaching goes on in this country and why. ${ }^{2}$

The results of this research have generated widespread interest and have been featured in several major education reports, including those issued by the National Commission on Teaching and America's Future and Education Week's widely read special supplement "Quality Counts."3 Notably, my findings have also been replicated. Several NCES analysts have also conducted statistical analyses of the same data and have reached the same conclusion-that there is an alarming level of underqualified teaching in American high schools. ${ }^{4}$ As a result, the problem of out-offield teaching has suddenly become a real concern in the realm of educational policy and has been widely reported and commented on in the national media. However, despite this attention, the problem of out-of-field teaching remains largely misunderstood.

In this article, I will summarize what my research has revealed about out-of-field teaching: how much of it goes on; to what extent it varies across different subjects, across different kinds of schools, and across different kinds of classrooms; and finally, the reasons for its prevalence in American schools.

\section{Measuring Out-of-Field Teaching}

Empirical research on the extent of underqualified and outof-field teaching faces serious problems surrounding the validity of both data and methods. In the first place, outof-field teaching is politically sensitive and can adversely effect school accreditation, and hence, researchers have been skeptical of data on out-of-field assignments obtained from local or state school officials (Haggstrom, DarlingHammond, Grissmer, 1988, p. 52; Robinson, 1985). ${ }^{5}$ One of the strengths of the SASS data on out-of-field teaching is that it is not obtained from school officials, nor is it obtained by asking teachers themselves if they are assigned to teach out of field. SASS collects extensive information on the daily course schedules and the education, pedagogical training and certification from its very large nationally representative sample of teachers. From these data, I independently calculate the amount of out-of-field teaching.

Empirical measurement of the extent of underqualified teaching is also difficult because there is surprisingly little consensus on how to define a "qualified teacher." There is almost universal agreement that teachers do matter and, moreover, there exists substantial empirical support for the reasonable proposition that student learning is affected by the qualifications of teachers. ${ }^{6}$ But there is a great deal of controversy concerning how much training and which kinds of preparation teachers ought to have to be considered adequately qualified (e.g., Haertel, 1991; Ingersoll, in press).

In my research, I began with the standard indicator by which school officials decide whether a candidate is qualified to teach a particular subject-if a teacher has a teaching certificate or license in the fields he or she teaches. The value of certification as an indicator of a qualified teacher is, however, one of the issues most hotly debated. The kinds of certification provided, the rigor of teacher certification requirements, and the quality of teacher training programs all vary widely across states (Tryneski, 1997). There is, for instance, heated controversy over whether teacher certification should or should not require a major or a minor in an academic discipline, rather than simply an education degree. Far more valid than certification as an indicator of a qualified teacher, many have argued, is the actual preparation teachers receive.

Probably the most precise method of assessing teachers' educational preparation is to count the actual number of undergraduate or graduate courses completed in any given field. But counting courses is also problematic. Analysts at NCES have found that, absent an analysis of actual course transcripts, teachers find it very difficult to accurately recollect the exact number of credits they have previously completed in different subjects (Chaney, 1994). A less precise but more reliable indicator of qualified teachers is whether they have a degree in the fields they teach. Other observers, however, have questioned the necessity of a degree and argue that "a good teacher can teach anything," regardless of education or training.

I decided to skirt this endless debate by adopting a minimal definition of a "qualified teacher" and by focusing on the most compelling case. ${ }^{7}$ My primary focus became discovering how many of those teaching core academic subjects at the secondary level do not have even minimal credentialsneither a major nor a minor-in their teaching fields. I counted both academic and education majors and minors. A college minor, of course, does not guarantee quality teaching, nor even a qualified teacher. My assumption was that adequately qualified teachers, especially at the secondary school level and especially in the core academic fields, ought to have, as a minimum prerequisite, at least a college minor in the subjects they teach. That is, my assumption was that for most teachers it is difficult, at best, to teach well what one does not know well. In short, I assumed that few parents would expect their teenagers to be taught, for example, 11th-grade trigonometry by a teacher who did not have a minor in math, no matter how bright the teacher. I found that, however, to be precisely the case for millions of students.

\section{How Widespread Is Out-of-Field Teaching?}

I found, for example, that about a third of all secondary school teachers who teach math do not have either a major or a minor in math, math education, or related disciplines like engineering or physics (see Table 1). About one quarter of all secondary school English teachers have neither a major nor minor in English or related subjects such as literature, communications, speech, journalism, English education, or reading education. In science, slightly lower levels-about one fifth of all secondary school teachers-do not have at least a minor in one of the sciences or in science education. Finally, about a fifth of social studies teachers are without at least a minor in any of the social sciences, public affairs, social studies education, or history. ${ }^{8}$

Whether I examined teachers without a major or minor or teachers without certification in their assigned fields, the numbers were similarly alarming. I found, for example, that 
Table 1

Percentage of Secondary School (Grades 7-12) Teachers in Each Field Without a Major or a Minor in That Field

\begin{tabular}{|c|c|c|c|c|c|c|c|}
\hline & English & Math & Science & $\begin{array}{c}\text { Life } \\
\text { science }\end{array}$ & $\begin{array}{l}\text { Physical } \\
\text { science }\end{array}$ & $\begin{array}{l}\text { Social } \\
\text { studies }\end{array}$ & History \\
\hline U.S. total & 24.3 & 33.1 & 20.3 & 33.1 & 56.5 & 19.9 & 53.1 \\
\hline $\begin{array}{l}\text { Public total } \\
\text { School poverty level }\end{array}$ & 24.1 & 31.4 & 19.9 & 32.9 & 56.9 & 19.3 & 53.1 \\
\hline $\begin{array}{l}\text { Low poverty } \\
\text { High poverty }\end{array}$ & $\begin{array}{l}20.1 \\
25.7\end{array}$ & $\begin{array}{l}26.8 \\
42.8\end{array}$ & $\begin{array}{l}17.5 \\
27.8\end{array}$ & $\begin{array}{l}29.2 \\
40.1\end{array}$ & $\begin{array}{l}51.3 \\
65.1\end{array}$ & $\begin{array}{l}15.8 \\
25.1\end{array}$ & $\begin{array}{l}46.4 \\
60.0\end{array}$ \\
\hline $\begin{array}{l}\text { School size } \\
\text { Small } \\
\text { Large }\end{array}$ & $\begin{array}{l}30.4 \\
22.4\end{array}$ & $\begin{array}{l}41.2 \\
27.5\end{array}$ & $\begin{array}{l}25.5 \\
17.6\end{array}$ & $\begin{array}{l}38.1 \\
30.1\end{array}$ & $\begin{array}{l}64.5 \\
53.7\end{array}$ & $\begin{array}{l}25.5 \\
17.2\end{array}$ & $\begin{array}{l}62.8 \\
48.1\end{array}$ \\
\hline $\begin{array}{l}\text { Teacher union } \\
\text { Member } \\
\text { Nonmember }\end{array}$ & $\begin{array}{l}24.3 \\
23.3\end{array}$ & $\begin{array}{l}31.2 \\
32.1\end{array}$ & $\begin{array}{l}19.1 \\
23.1\end{array}$ & $\begin{array}{l}32.0 \\
36.3\end{array}$ & $\begin{array}{l}55.7 \\
61.7\end{array}$ & $\begin{array}{l}18.5 \\
22.1\end{array}$ & $\begin{array}{l}52.9 \\
53.9\end{array}$ \\
\hline $\begin{array}{c}\text { Teacher's experience } \\
\text { Less than } 5 \text { years } \\
\text { More than } 25 \text { years }\end{array}$ & $\begin{array}{l}26.1 \\
17.8\end{array}$ & $\begin{array}{l}31.7 \\
25.6\end{array}$ & $\begin{array}{l}19.7 \\
13.3\end{array}$ & $\begin{array}{l}36.1 \\
24.5\end{array}$ & $\begin{array}{l}56.8 \\
52.7\end{array}$ & $\begin{array}{l}21.3 \\
14.8\end{array}$ & $\begin{array}{l}54.8 \\
48.7\end{array}$ \\
\hline $\begin{array}{l}\text { Private total } \\
\text { School size } \\
\text { Small } \\
\text { Large }\end{array}$ & $\begin{array}{l}33.6 \\
19.9\end{array}$ & $\begin{array}{l}53.1 \\
32.4\end{array}$ & $\begin{array}{l}31.8 \\
15.2\end{array}$ & $\begin{array}{l}34.0 \\
44.5 \\
21.6\end{array}$ & $\begin{array}{l}53.9 \\
71.5 \\
30.6\end{array}$ & $\begin{array}{l}23.9 \\
29.6 \\
11.5\end{array}$ & $\begin{array}{l}53.1 \\
63.5 \\
40.4\end{array}$ \\
\hline $\begin{array}{l}\text { Teacher union } \\
\text { Member } \\
\text { Nonmember }\end{array}$ & $\begin{array}{l}42.2 \\
23.3\end{array}$ & $\begin{array}{l}36.4 \\
42.8\end{array}$ & $\begin{array}{l}17.3 \\
23.8\end{array}$ & $\begin{array}{l}36.5 \\
33.6\end{array}$ & $\begin{array}{l}49.5 \\
54.3\end{array}$ & $\begin{array}{l}13.9 \\
24.9\end{array}$ & $\begin{array}{l}41.2 \\
54.5\end{array}$ \\
\hline $\begin{array}{c}\text { Teacher's experience } \\
\text { Less than } 5 \text { years } \\
\text { More than } 25 \text { years }\end{array}$ & $\begin{array}{l}35.5 \\
25.4\end{array}$ & $\begin{array}{l}49.0 \\
25.9\end{array}$ & $\begin{array}{l}23.2 \\
14.5\end{array}$ & $\begin{array}{l}35.4 \\
18.9\end{array}$ & $\begin{array}{l}55.7 \\
30.5\end{array}$ & $\begin{array}{l}29.9 \\
20.5\end{array}$ & $\begin{array}{l}60.7 \\
26.6\end{array}$ \\
\hline
\end{tabular}

about a third of public secondary math teachers do not have teaching certificates in math (see Figure 1). ${ }^{9}$ But focusing on those without certificates can lead one to underestimate the amount of underqualified teaching within broad, multidisciplinarian fields such as science and social studies. Teachers in these fields are routinely required to teach any of a wide array of subjects within the department. Even if they are certified in the field, however, many of these teachers may not be qualified to teach all the disciplines within the larger field. For example, a teacher with a degree in biology, even though certified in science, may not be qualified to teach physics. Indeed, when I examined science and social studies more closely, I found high levels of within-field, out-of-field teaching. For example, over half of teachers teaching physical science classes (chemistry, physics, earth science, or space science) are without an academic major or minor in any one of the physical sciences. Likewise, over half of all those teaching secondary school history in this country are without an academic major or minor in history itself. ${ }^{10}$

Several points must be stressed concerning all these data. First, there is no doubt some of these out-of-field teachers may actually be qualified, despite not having a minor or major in the subject. Some may be qualified by virtue of knowledge gained through previous jobs, through life ex- periences, or through informal training. Others may have completed substantial college course work in a field and may even have a teaching certificate, but not have gotten a major or minor. In Georgia, for instance, because school accreditation regulations require teachers to have at least 20 hours of college credit (about four courses) in a field to teach it, many of those in the state assigned to teach out of their fields probably do have some background.

Moreover, out-of-field teaching is not the norm for most teachers. Most secondary school teachers have a main field or a primary department in which they teach, and most do have either a certificate or a degree in this main field. But many teachers, especially at the secondary-school level, are assigned to teach some classes in other fields or departments. Mathematics teachers, for example, may not simply teach math; they may also be assigned to teach some English. It is in these other assignments that teachers most often have little education.

But my initial premise was that even a moderate number of teachers lacking the minimal prerequisite of a college minor signals the existence of serious problems in our schools, and the data clearly indicate that this is the case. In any given year, out-of-field teaching takes place in well over half of all secondary schools in the U.S. Indeed, when I upgraded the definition of a "qualified" teacher, for instance, to 


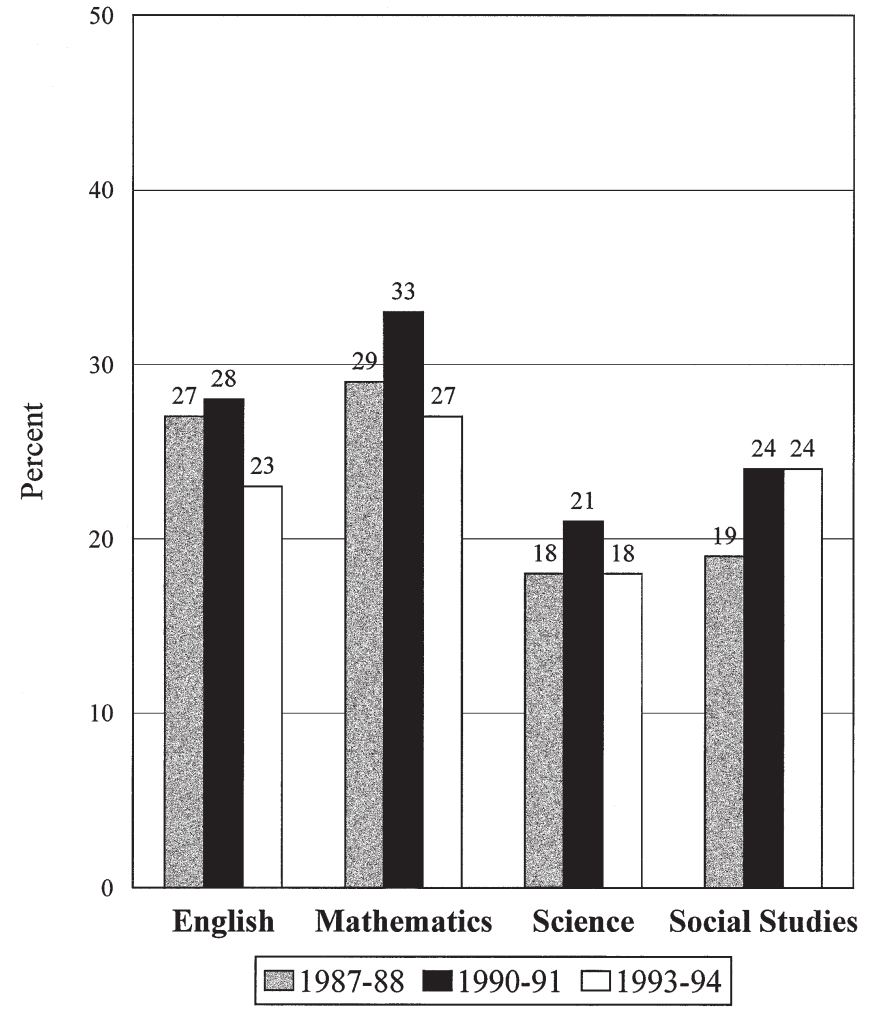

FIGURE 1. Percentage of public secondary school (grades 7-12) teachers in each field without certification in that field.

include only those who held both a college major and a teaching certificate in the field, the amount of out-of-field teaching substantially increased. Moreover, out-of-field teaching does not appear to be going away; I found that levels of outof-field teaching have changed little from the late 1980s to the mid-1990s (see Figures 1 or 2). ${ }^{11}$ Finally, it is important to note that the actual numbers of students affected are not trivial. For example, in each of the fields of English, math, and history, every year well over four million secondary-level students are taught by teachers with neither a major nor a minor in the field.

\section{The Consequences of Out-of-Field Teaching}

The negative consequences of such high levels of out-offield teaching are obvious. Given the current national concern over the relatively low achievement test scores of U.S. students in comparison with students in other nations, the data on levels of out-of-field teaching seem particularly relevant. Is it any surprise that science achievement is so low given that even at the 12th-grade level $41 \%$ of public school students in physical science classes are taught by someone with neither a major nor a minor in either chemistry, physics, or earth science?

Some of the most important consequences of out-of-field teaching are, however, probably those not easily quantified. The effects of being taught by a teacher without a strong background in a field may be just the kind of outcome not captured in student scores on short-answer, standardized examinations. Teachers assigned to teach a subject for which they have little background are probably more likely to overly rely on textbooks, and the kinds of learning obtained from textbooks are probably what standardized examina-

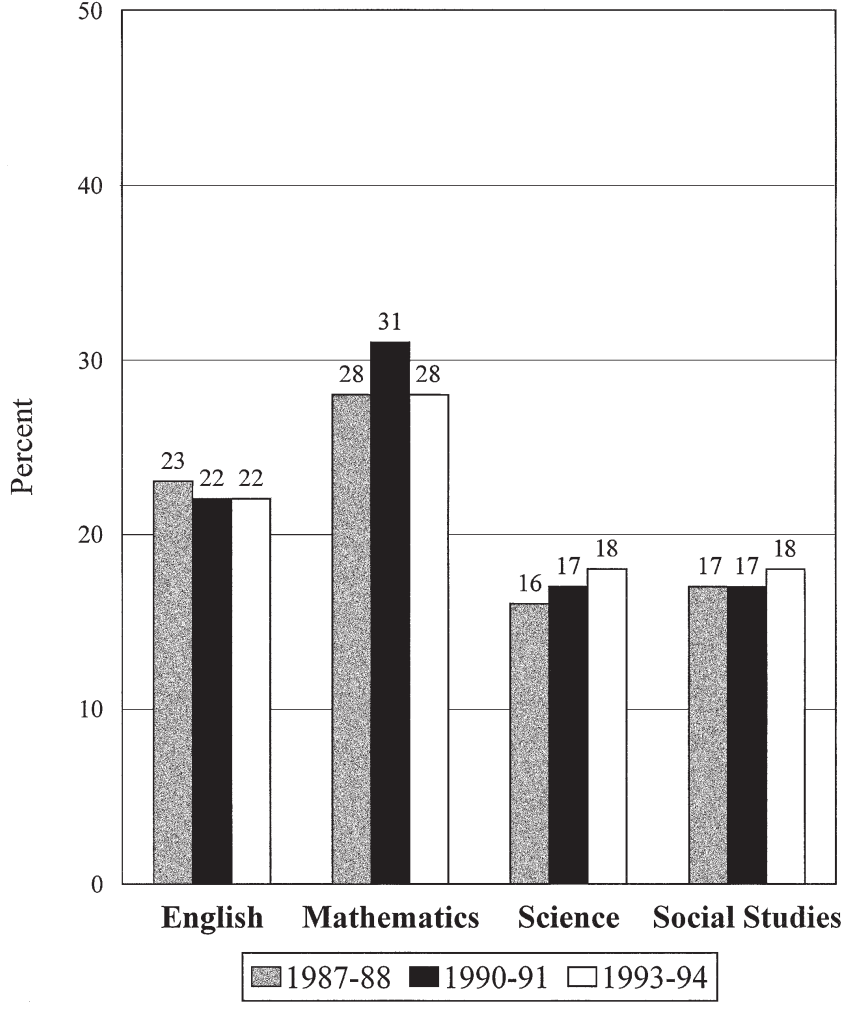

FIGURE 2. Percentage of public high school (grades 9-12) teachers in each field without a major or minor in that field.

tions best capture. But one can easily imagine the limitations imposed by a lack of subject background on a teacher's ability to teach for critical thinking and to engage the students' interest in the subject - the kinds of learning probably not well captured by standardized examinations.

High levels of out-of-field assignments could also negatively affect the learning environment for all students in schools, not just for those students unlucky enough to be taught by out-of-field teachers. The assignment of teachers to teach fields in which they have no training could change the allocation of their preparation time across all of their courses-decreasing the amount of time they spend preparing for their other courses in order to prepare for the one(s) for which they have no background.

There are, moreover, consequences for teachers to be considered. Having to cope with out-of-field assignments comes on top of an already burdensome teaching load for most public secondary teachers who are assigned an average of 128 students and five classes per day. What is the impact on teachers' sense of efficacy of having to teach courses for which they have little formal background preparation? Preliminary multivariate analyses I have conducted with SASS show that out-of-field assignments are associated with decreases in teachers' morale and commitment. Moreover, one might also ask, does out-of-field teaching have any effect on the legitimacy and authority of teachers and, hence, classroom discipline?

\section{Do Schools Vary in Their Levels of Out-of-Field Teaching?}

The data also show that, while out-of-field assignments exist in the majority of secondary schools, there are striking 
differences in the amount of out-of-field teaching across different types of schools. Some of these variations, moreover, run counter to conventional wisdom.

It is, for instance, widely believed that the most needy students in the U.S.- those from poor and low-income communities-are often taught by the least-qualified teachers. This, of course, is held up as a major reason why such students often perform poorly in educational assessments (e.g., Darling-Hammond, 1987; Kozol, 1991; Oakes, 1990). The data show that, indeed, school poverty levels are clearly related to the amount of out-of-field teaching. That is, in most fields, teachers in high-poverty schools are more likely to be teaching out of field than are teachers in more affluent schools. For example, a quarter of social studies teachers in high-poverty schools, as opposed to $16 \%$ in low-poverty schools, do not have at least a minor in social studies or related disciplines (see Table 1). ${ }^{12}$

But more affluent schools are, by no means, free of outof-field teaching, and interestingly, school poverty is not the only, nor even the most important, school characteristic related to the degree of out-of-field teaching. Far more important sources of variation for out-of-field teaching than school poverty levels are school sector and school size. Small schools (fewer than 300 students) have higher levels of out-of-field teaching in each of the core academic fields than do larger schools (600 or more). This gap is especially striking in the private sector. In a number of fields, large private schools have among the lowest overall levels of out-offield teaching. On the other hand, small private schools (which represent over $80 \%$ of all private schools) have the highest overall levels of out-of-field teaching. This suggests there is a large degree of diversity, at least regarding teacher qualifications, in the private sector-something often overlooked in the ongoing debate over public-versus-private schooling. Moreover, the finding that school size is related to the extent of underqualified teaching questions the "small is beautiful" notion that is currently popular among many education researchers and policymakers. In this view, large schools are more impersonal, alienated, inflexible, bureaucratic, and hence provide less sense of cohesion, belongingness, and community. The result, from this viewpoint, is that large schools are less effective places for students to learn and grow (for a review, see Bryk, Lee, \& Smith, 1990). These data suggest, however, that one possible disadvantage of smaller schools, often overlooked in the debates over the relative merits of small and large, is a greater degree of underqualified teaching. Small schools most likely find it more difficult to allow staff specialization, and as a result, teachers in these schools are more often required to be generalists.

\section{Do Classrooms Vary in Their Levels of Out-of-Field Teaching?}

Out-of-field teaching is also not equally distributed across different types of classes within schools. The data on student ability group/track differences are especially striking because they substantiate a long-suspected pattern of unequal access to qualified teachers. In addition to betweenschool inequities, critics of educational inequality have also argued that students in low-achieving and low-track classes in schools are disproportionately minority and poor and have both the greatest need for, but the least access to, highquality teachers (e.g., Darling-Hammond, 1987; Kozol, 1991; Oakes, 1990).

In most fields, students in high-track classes are less likely to be taught by out-of-field teachers than are those in low-track classes (see Table 2). ${ }^{13}$ For instance, about one 10th of students in high-track English classes are taught by out-of-field teachers. But about one quarter of those in lowtrack English classes receive out-of-field teaching. There are, however, fewer differences in levels of out-of-field teaching between the two higher tracks-the honors/ gifted/AP track and the college-preparatory track. ${ }^{14}$

On the other hand, it needs to be noted that some educators have argued that because qualified teachers are a scarce resource, it makes sense to place the most qualified teach-

Table 2

Percentage of Public Secondary School (Grades 7-12) Students in Each Field Taught by Teachers Without a Major or a Minor in That Field

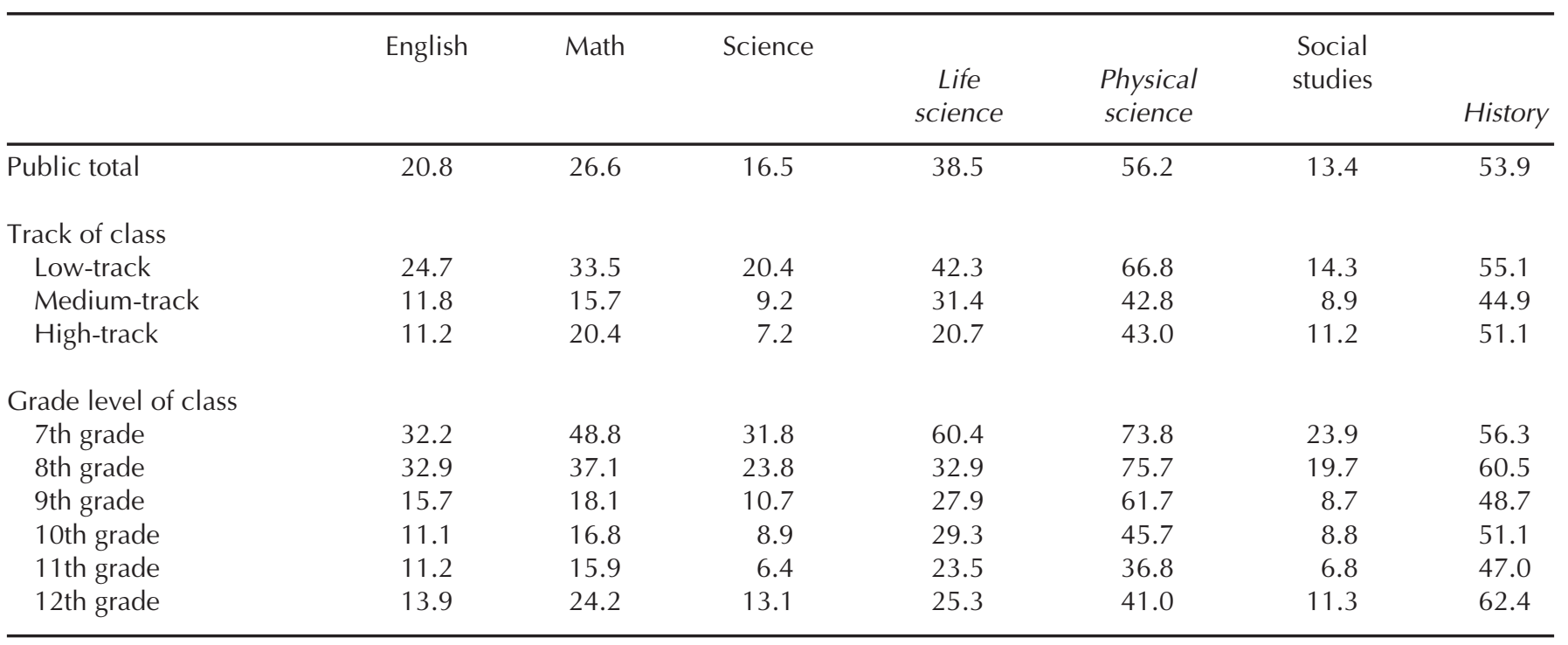


ers in the most advanced courses. In this view, high-track courses, such as classes for honors or gifted students or classes at the senior-high grade levels, require a greater level of mastery and training on the part of teachers than do those at the lower-track or junior-high levels. Hence, in this latter view, assignment of the most qualified teachers to teach at the highest levels is not a matter of inequality, but of efficiency (e.g., Glazer, 1987).

It is important to mention this counterview because, while the data show that low-track classes do, indeed, have more out-of-field teaching, class track is not the only, nor even the most salient, factor related to within-school differences in out-of-field teaching. There are even greater differences between the junior secondary-school grade levels and the senior secondary-school grade levels. In most fields, students in grade 7 are more likely to receive out-of-field teaching than are 12th-grade students. For example, about one third of science students in 7th grade are taught by teachers without at least a minor in any of the sciences, while this is true for only about a 10th of the science students in 12th grade. There are not, however, distinct differences among the senior-high grade levels. Ninth-grade students, for example, are not necessarily more likely to be taught by an out-of-field teacher than are 12th-grade students.

\section{Why Is Out-of-Field Teaching So Widespread?}

The crucial question, and a source of great misunderstanding, is why so many teachers are teaching subjects for which they have little background. Of course, some degree of mismatch or out-of-field teaching is probably unavoidable. School administrators charged with the task of offering programs in a range of required and elective subjects may often be forced to make spot decisions concerning the assignment of available faculty to an array of changing course offerings. But to advocates of raising standards of teacher quality, whether they be teachers, policymakers, or parents of schoolage children, the levels of out-of-field teaching documented by this research have been a source of concern. With this concern, moreover, has come a rush to affix blame. Typically, policymakers, commentators, and researchers have offered three explanations (and sources of fault) for the high rates of out-of-field teaching: inadequate training or education of teachers, inflexible teacher unions, and shortages of teachers. A close examination of the data on the conditions and character of the teaching occupation reveals that each of these views seriously misunderstands the source of the problem.

\section{Teacher Training}

Many people immediately assume that out-of-field teaching is a problem of poorly prepared teachers. In this view, the preparation of teachers in college or university training programs lacks adequate rigor, breadth, and depth, especially in academic and substantive course work, resulting in high levels of out-of-field teaching. ${ }^{15}$ Proponents of this view typically assume that the problem can be remedied by requiring prospective teachers to complete a "real" undergraduate major in an academic discipline. This explanation of out-of-field teaching is partly correct, but it overlooks an important source of the problem.

The data show that only $1 \%$ of all teachers in the U.S. have not completed a college education-that is, do not have bachelor's degrees; indeed, almost half of all public school teachers have graduate degrees. Moreover, $94 \%$ of public school teachers and, surprisingly, over half of private school teachers hold regular, state-approved teaching certificates. Many of these teachers, of course, have education and not academic degrees. But having an education degree does not mean a teacher lacks training in a particular subject or specialty.

Table 3 shows, for example, the education of secondary school math teachers in the U.S. ${ }^{16}$ Thirty-three percent of those teaching math do not have a major or a minor in math, math education, or related disciplines such as physics or engineering. As in Table 1, I define these as "out of field." Of these, very few ( $4 \%$ of the total) have only a generic major or minor in education, such as secondary education or curriculum. In short, those teaching math out of field do not lack degrees or training in a subject; they lack degrees in math or math education.

Of course, critics of teacher education have long pointed out that subject-area education degrees, such as math education, have tended to be overloaded with required courses in education to the neglect of course work in the subject itself. Indeed, it is precisely because of such problems that many states have, over the past decade, upgraded teacher education by, among other things, requiring education majors to complete substantial course work in an academic discipline. Currently, at the University of Georgia, for instance, a degree in math education requires as much course work in the math department as does a degree in math itself.

My point is not to dismiss the importance of teacher education reforms. There is no question that the teaching force has and can continue to benefit from higher education and training standards. My point is that such reforms alone will not eliminate the problem of out-of-field teaching because they do not address a major source of the problem. The source of out-of-field teaching lies not only in the amount

Table 3

Education (Undergraduate and Graduate Majors and Minors) of Secondary School (Grades 7-12) Math Teachers

Percentages

\section{In-field}

Academic major or minor in math $33 \%$

Academic major or minor in physics or $4 \%$ engineering

Education major or minor in math education Total in-field

$30 \%$ $67 \%$

\section{Out-of-field}

Academic major or minor in subject other than math, physics, or engineering (e.g., English, art, etc.)

Education major or minor in subject other than math education (e.g., English education, art education, etc.)

Education major or minor in general field (e.g., secondary education, curriculum, guidance, etc.)

No bachelor's or master's

Total out-of-field
$11 \%$

$4 \%$

$1 \%$

$33 \%$ 
of education or training teachers have, but in the lack of fit between teachers' fields of preparation and their teaching assignments. Many teachers are assigned by their principals to teach classes that do not match the field of their degree or certification or both. ${ }^{17}$ In short, mandating more rigorous academic requirements for prospective teachers will help little if large numbers of such teachers continue to be assigned to teach subjects other than those for which they were trained.

The same logic applies to two other related popular initiatives-curricular revision and professional development for teachers. Every year, educational organizations and publishers produce hundreds of new curricular packages, products, and techniques that are widely disseminated to teachers through in-service training and other programs. Familiarity with the most up-to-date materials in one's field of expertise is no doubt a good idea, but provides little help if one is then assigned to teach another subject.

\section{Teacher Unions}

A second explanation for out-of-field teaching assumes that the fault lies with teacher unions. In this view, self-serving work rules promulgated by teacher unions, especially seniority rules, are the main reason that classrooms are staffed with underqualified teachers. The use and abuse of such rules, according to these critics, is especially prevalent in times of teacher oversupply, when school officials face the need to cut or shifting staff because of fiscal cutbacks or declining enrollments. In such situations, "last-hired, firstfired" union seniority rules require that more experienced teachers must be given priority, regardless of competence. As a result, so the argument goes, veteran teachers are often given out-of-field assignments, junior staff are transferred or laid off, and students suffer accordingly (e.g., Toch, 1996).

The data do not support this explanation of out-of-field teaching. Beginning teachers are more prone than experienced teachers to be misassigned, and both public and private schools with unions usually have less, not more, out-of-field teaching (see Table 1). Moreover, teacher oversupply and layoffs are not common; for instance, in 1993-94, only $13 \%$ of public school districts reported that they laid off any teachers because of budget limitations, declining enrollments, or elimination of courses, and these layoffs accounted for less than $1 \%$ of the teaching force.

Union work rules certainly have an impact on the management and administration of schools, and depending on one's viewpoint, this impact may be positive or negative, but eliminating teacher unions will not eliminate out-offield teaching.

\section{Teacher Shortages}

The most popular explanation of the problem of out-of-field teaching blames teacher shortages. This view holds that shortfalls in the number of available teachers primarily because of increasing student enrollments and a "graying" teaching work force have forced many school systems to resort to lowering standards to fill teaching openings, the net effect of which is high levels of out-of-field teaching.

The data suggest that this last view is partly correct and partly incorrect. The data show that, consistent with the shortage predictions, demand for teachers has, in fact, increased since the mid-1980s. From 1984 to 1996, student enrollments increased $15 \%$, an overwhelming majority of schools have had job openings for teachers, and the size of the teaching work force $(\mathrm{K}-12)$ increased about 22\% (Snyder, Hoffman, \& Geddes, 1997, pp. 12-13). More important, a substantial number of schools, although not a majority, do report some degree of difficulty filling their teaching openings with qualified candidates. For instance, in the 1993-94 school year, $35 \%$ of secondary schools had openings for English teachers, and about one quarter of these indicated they had some degree of difficulty filling these openings (see Figure 3). ${ }^{18}$ Despite these difficulties, however, once school begins in the autumn, very few positions remain unfilled or vacant (e.g., less than $4 \%$ of all new openings in 1993-94).

In reality, of course, schools simply cannot leave teaching positions unfilled. When faced with difficulties in obtaining suitable candidates, administrators tell us they most commonly do three things: hire less-qualified teachers, assign teachers trained in another field or grade level to teach in the understaffed area, and make extensive use of substitute teachers (see Figure 4). Each of these particular coping strategies can result in out-of-field teaching.

There are, however, several problems with the shortage explanation of out-of-field teaching. First, it cannot explain the high levels of out-of-field teaching in fields such as English and social studies that have long been known to have surpluses. Moreover, embedded in most discussions of teacher supply and demand is the mistaken notion that hiring difficulties (and out-of-field teaching) are a result of too few able candidates available to enter teaching. While it is true that student enrollments are increasing, the demand for new teachers is not primarily because of these increases. The demand for new teachers is primarily due to teachers moving from or leaving their jobs at far higher rates than in many other occupations. In recent years, the vast majority

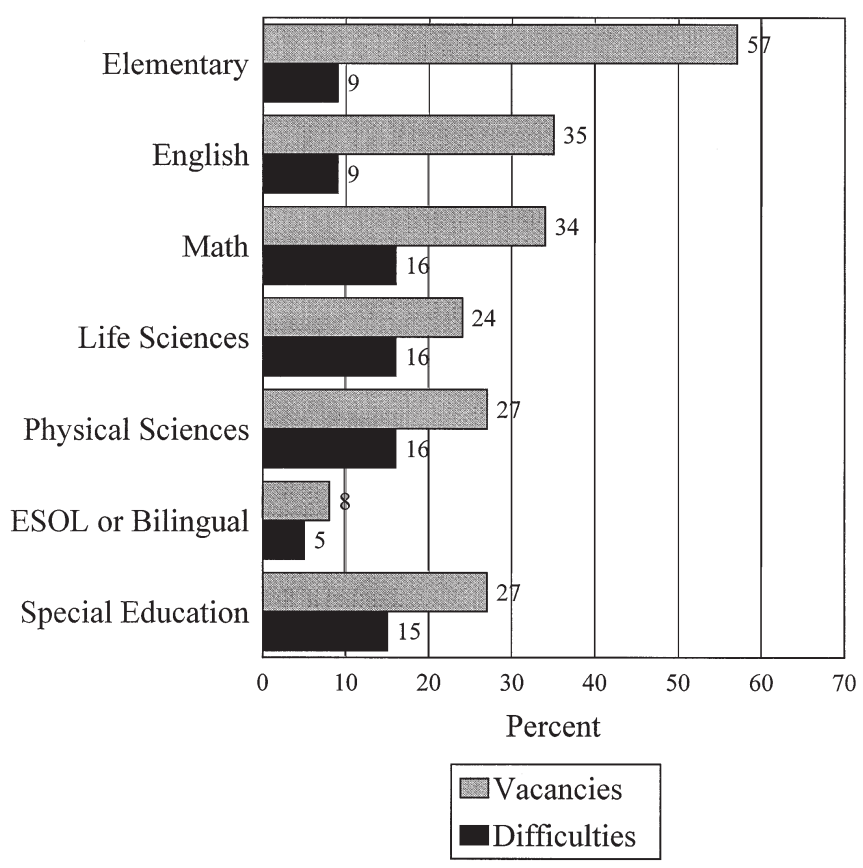

FIGURE 3. Percentage schools with teaching vacancies and percentage schools with difficulties filling teaching vacancies, by field. 


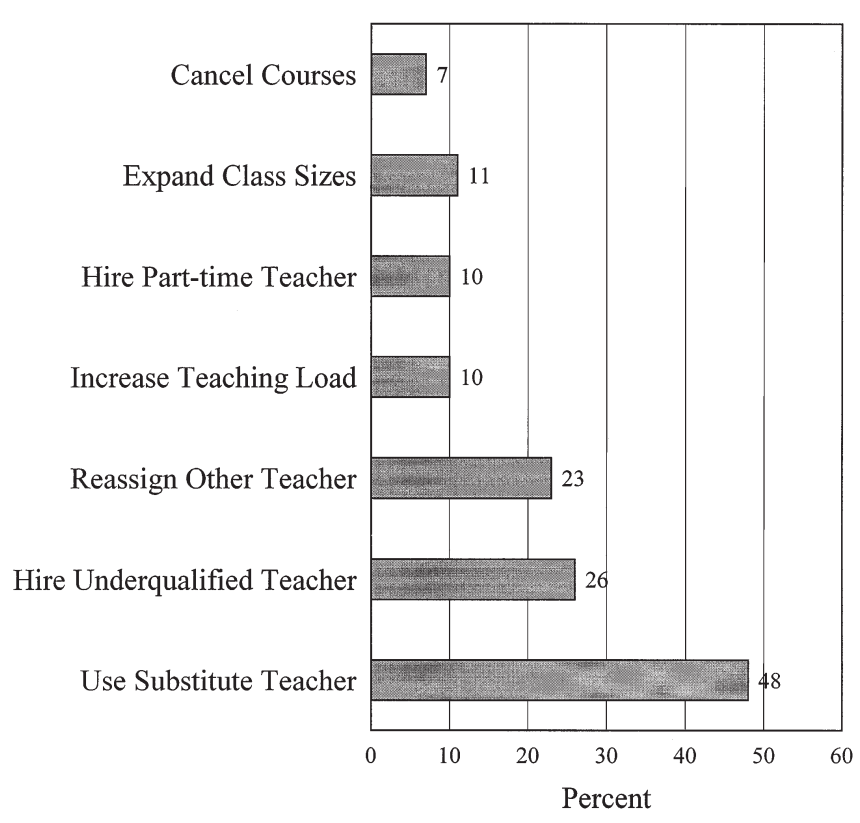

FIGURE 4. Of schools with difficulties filling teaching vacancies, percentage using various methods to cover their vacancies.

of new hires are simply replacements for those who have just departed. For instance, about 286,200 teachers (excluding within-district transfers) were newly hired by schools just prior to the 1993-94 school year. But in the following 12 months, about 213,000 teachers-an amount equivalent to $75 \%$ of those just hired-left the occupation altogether. Moreover, while it is true that teacher retirements are increasing, teacher turnover appears to have little to do with a graying work force. Less than one fifth of total turnover is for the reason of retirement. In contrast, the high rates of teacher turnover that plague schools are far more often a result of two related causes: teachers seeking to better their careers and/or teachers dissatisfied with teaching as a career (see Figure 5). ${ }^{19}$

Hence, there is no question that some schools do have staffing problems. That is, some schools do face difficulties finding qualified people to fill all their positions, and this does result in misassignments. Moreover, these difficulties may be partly because of inadequate numbers of particular types of teachers in particular locales. But the data suggest that these hiring difficulties are not primarily due to shortages in the conventional sense of a paucity of available candidates. Rather, the data suggest that the continual demand to hire new teachers is largely a result of too many teachers prematurely exiting their jobs.

The implications of this distinction for policy are important. Initiatives designed to recruit new candidates into teaching such as mid-career change and alternative certification programs, although perhaps worthwhile in some ways, will not solve the problem of underqualified teachers in classrooms if they do not also address the factor that, the data suggest, does lead to severe staffing inadequacies in schools: too little teacher retention. In short, recruiting more teachers will help little if large numbers of such teachers then leave.

Multivariate analyses I have conducted using SASS show that low salaries, inadequate support from administrators,

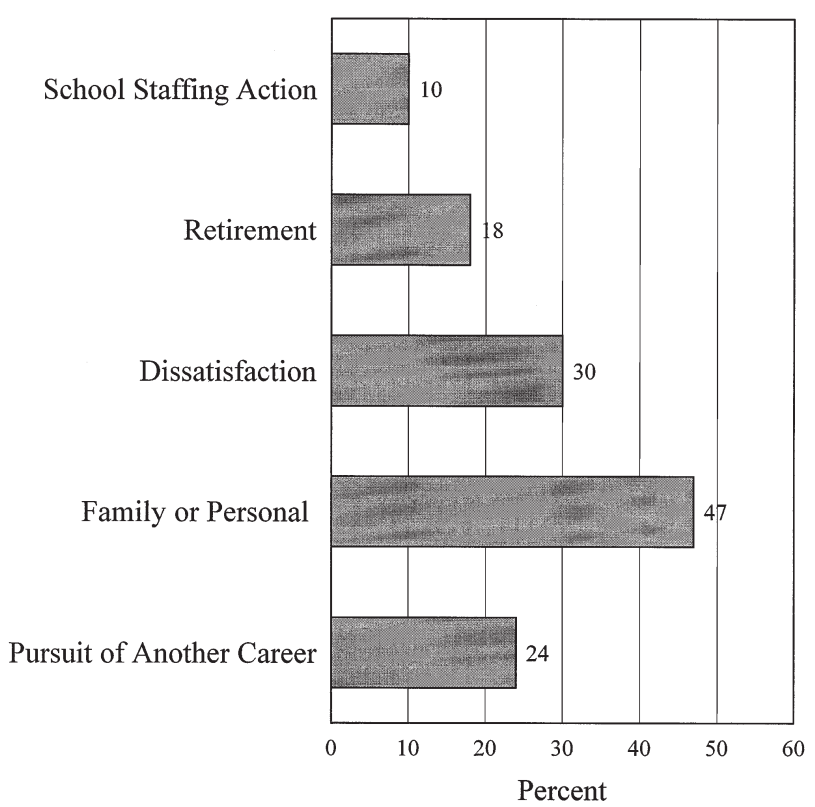

FIGURE 5. Percentage teachers giving various reasons for turnover.

rampant student discipline problems, and little faculty input into school decision-making all contribute to high rates of teacher turnover. ${ }^{20}$ Improving these things would decrease turnover, which would quickly eliminate the socalled shortages. It would also remove some of the motive for out-of-field assignments in the first place. But it would not eliminate them. The data suggest that staffing problems resulting from supply-demand imbalances do not account for all, or even most, out-of-field teaching. If less than one 10th of secondary schools had difficulty filling their openings for English teachers in 1993, why then were a quarter of all public school English teachers uncertified in English in that same year? Likewise, if only $16 \%$ of secondary schools reported problems filling their openings for math teachers, why did a third of all math teachers not have a major or minor in math?

\section{The Root Cause of Out-of-Field Teaching- An Alternative Hypothesis}

There is, I have come to believe, a far more fundamental problem facing the teaching occupation that results in the problem of out-of-field teaching. Below, I offer this alternative explanation as a hypothesis that warrants further empirical investigation-a project that I am currently undertaking. This alternative view is drawn from the sociology of organizations and occupations and also from my own experiences as a former high school teacher.

Unlike in many European and Asian nations, in this country, elementary and secondary school teaching is largely treated as lower-status work and teachers as semi-skilled workers. Since the turn of the century, American educators have sought to promote the view that teaching, like other professions, is a highly complex kind of work, requiring specialized knowledge and skill and, like other professions, deserves commensurate prestige, authority, and compensation. These efforts have, however, met only limited success. ${ }^{21}$ 
It is the continuing treatment and status of teaching as a "semi-profession" that has resulted, I believe, in what the data tell us-that teaching is plagued by problems of both recruitment and retention, and out-of-field teaching is not simply an emergency condition, but a common practice in the majority of secondary schools in this country. A brief look at some of the occupational and organizational conditions of teaching illustrates this hypothesis.

Unlike traditional professions, teachers have only limited authority over key work-place decisions. Teachers, or instance, have little say over which courses they are assigned-or misassigned-to teach. The allocation of teaching assignments is usually the prerogative of school principals (Carey \& Farris, 1994; Ingersoll, 1993).

Principals not only have the authority to decide who teaches which courses; they have an unusual degree of discretion. Like traditional professions, teaching is subject to an elaborate array of state licensing requirements designed to assure the basic preparation and competence of practioners. Unlike traditional professions, however, there is little regulation of how teachers are actually employed and assigned. Most states do, indeed, possess explicit policies

\section{The crucial question, and a source of great misunderstanding, is why so many teachers are teaching subjects for which they have little background.}

acknowledging misassignment as an unsound practice. But unknown to the public, misassignment of teachers typically is permitted by state law. Some states have no regulations concerning teacher assignment. Others have regulations delimiting the extent to which administrators may assign teachers to teach subjects for which they are not officially qualified. But these standards are often not rigorous, penalties for noncompliance by schools are weak or rarely enforced, and finally, most states routinely allow local school administrators to bypass even the limited requirements that do exist (Robinson, 1985). The result is that misassignment is an accepted administrative technique.

In this context, many principals find that assigning teachers to teach out of their fields is often not only legal but more convenient, less expensive, or less time-consuming that the alternatives. For example, rather than find and hire a new physics teacher to teach a newly state-mandated physics curriculum, a principal may find it less expensive to assign a biology teacher to teach it. When faced with the choice between hiring a fully qualified candidate for an English position or hiring a less qualified candidate who is also willing to coach a major varsity sport, a principal may find it more convenient to do the latter. If a math teacher suddenly leaves in the middle of the year, a principal may find it faster and cheaper to hire a readily available, but not fully qualified, substitute teacher rather than conduct a formal search for a new teacher. Or alternatively, the principal might assign a couple of English and social studies teachers to each "cover" a section or two in math. The degree to which a school is faced with problems of recruitment or retention may shape the extent to which the principal relies on these options, but they are available to almost all schools and used by many.

The comparison with traditional professions is stark. Few would require cardiologists to deliver babies, real estate lawyers to defend criminal cases, chemical engineers to design bridges, or sociology professors to teach English. The commonly held assumption is that such traditional professions require a great deal of skill and training - that is, expertise-and hence, specialization is assumed necessary. In contrast, underlying out-of-field teaching is the assumption that elementary and secondary school teaching require far less skill, training, and expertise than these traditional professions, and hence, specialization is assumed less necessary.

Some would argue, of course, that teaching does, in fact, require less expertise and less specialization than traditional professions. And there may be some degree of truth to this; teaching may, indeed, be less complex than some kinds of work. But those who have spent time in classrooms know that high-quality teaching requires a great deal of expertise and skill and that teachers are not like interchangeable blocks that can be placed in any empty slot regardless of their type of training. Good teaching entails a complex combination of art, craft, and science that the best contemporary research has begun to insightfully illuminate. It requires expertise in at least three areas: knowledge of the subject (knowing what to teach), skill in teaching (knowing how to teach) and also what Shulman (1986) has called pedagogical content knowledge-knowing which method to use with particular topics, with particular kinds of students, and in particular kinds of settings. In short, the managerial choice to misassign teachers may save time and money for the school and, ultimately, for the taxpayer, but it is not cost-free.

The policy and reform implications of my alternative view of out-of-field teaching are clear. The way to make sure there are qualfied teachers in every classroom is not, for example, to shift the blame to teachers, their unions, or larger forces of supply and demand. These divert attention from the underlying problem - the way schools are managed and mismanaged and the continuing treatment of teaching as semiskilled work. Morever, reforms emanating from these viewpoints may do more harm than good. For instance, recruitment and alternative training programs that lower training and hiring standards contribute to the underlying problem by further eroding the already-low status of teaching.

In the short term, there are a number of things school officials could do to reduce or prevent out-of-field teaching. In high-demand fields, schools could, for example, offer incentives or provide free retraining to attract and retain teachers. The data indicate that fewer than one fifth of schools currently offer these options. Moreover, principals could cut back on out-of-field assignments for beginning teachers. New teachers leave the occupation at very high rates, and high rates of teacher turnover mean that schools are faced with a constant need to recruit and hire new teachers to fill vacated positions (e.g., Murnane, Singer, Willett, Kemple, \& Olsen, 1992). Disproportionately burdening be- 


\section{Appendix \\ Definitions of Core Academic Fields}

\begin{tabular}{|c|c|c|}
\hline Fields & $\begin{array}{l}\text { Teachers' majors } \\
\text { and minors }\end{array}$ & $\begin{array}{l}\text { Teachers' course } \\
\text { assignments }\end{array}$ \\
\hline Social studies & $\begin{array}{l}\text { Psychology } \\
\text { Public affairs \& services } \\
\text { Social studies/social science education } \\
\text { Economics } \\
\text { History } \\
\text { Political science } \\
\text { Sociology } \\
\text { Other social sciences } \\
\text { Other area, ethnic studies }\end{array}$ & $\begin{array}{l}\text { Social studies } \\
\text { History } \\
\text { World civilization } \\
\text { Political science/government } \\
\text { Geography } \\
\text { Economics } \\
\text { Civics } \\
\text { Sociology/social organization } \\
\text { Other social science } \\
\text { Psychology }\end{array}$ \\
\hline History & History & $\begin{array}{l}\text { History } \\
\text { World civilization }\end{array}$ \\
\hline Science & $\begin{array}{l}\text { Science education } \\
\text { Biology } \\
\text { Chemistry } \\
\text { Earth science/geology } \\
\text { Physics } \\
\text { Other natural sciences }\end{array}$ & $\begin{array}{l}\text { General science } \\
\text { Biology/life science } \\
\text { Chemistry } \\
\text { Physics } \\
\text { Geology/earth } \\
\text { Science/space science } \\
\text { Other physical science } \\
\text { Other natural science }\end{array}$ \\
\hline Life science & Biology & Biology/life science \\
\hline Physical science & $\begin{array}{l}\text { Earth science/geology } \\
\text { Physics } \\
\text { Chemistry }\end{array}$ & $\begin{array}{l}\text { Chemistry } \\
\text { Physics } \\
\text { Geology/earth } \\
\text { Science/space science } \\
\text { Other physical science }\end{array}$ \\
\hline English & $\begin{array}{l}\text { Communications \& journalism } \\
\text { English } \\
\text { English education } \\
\text { Literature } \\
\text { Reading education } \\
\text { Speech }\end{array}$ & $\begin{array}{l}\text { Literature } \\
\text { Composition/journalism/creative writing } \\
\text { Reading } \\
\text { Other English/language arts courses }\end{array}$ \\
\hline Mathematics & $\begin{array}{l}\text { Engineering } \\
\text { Mathematics } \\
\text { Mathematics education } \\
\text { Physics }\end{array}$ & $\begin{array}{l}\text { General mathematics } \\
\text { Business math } \\
\text { Algebra, elementary } \\
\text { Algebra, intermediate } \\
\text { Algebra, advanced } \\
\text { Geometry, plane/solid } \\
\text { Trigonometry } \\
\text { Analytical geometry } \\
\text { Probability/statistics } \\
\text { Calculus } \\
\text { Other mathematics }\end{array}$ \\
\hline
\end{tabular}

ginners with out-of-field courses only further contributes to this problem.

Ultimately, in the long term, however, the way to upgrade the quality of teaching and teachers is to upgrade the quality of the teaching job. Well-paid, well-respected occupations that offer good working conditions rarely have difficulties with recruitment or retention. If they do, they do not resort to lowering standards as a coping mechanism. If we treated teaching as a highly valued profession, one requiring expertise and skill, there would be no problem attracting and retaining more than enough excellent teachers, and there would be little problem ensuring that all classrooms were staffed with qualified teachers. 


\section{Notes}

This article draws from an earlier research project on teacher supply, demand, and quality that I undertook under the auspices of the American Institutes for Research and that was funded by the National Center for Education Statistics of the U.S. Department of Education (Contract No. RN93140001). The views expressed in this article are solely mine. Earlier versions of this article were presented at the annual meetings of the American Sociological Association, August 1994, and of the American Educational Research Association, April 1995. Thanks are due to Mei Han and Chuck Keil of the American Institutes of Research for assistance with the data analysis. Thanks are also due to Sharon Bobbitt, Tom Smith, Don McLaughlin, Jay Chambers, Neil Theobald, Dan Kasprzyk, Marilyn McMillen, Mary Rollefson, and Susan Ahmed for many helpful comments during the course of the research project as a whole.

${ }^{1}$ NCES conceived SASS to fill a long-noted void of nationally representative data on the staffing, occupational, and organizational aspects of elementary and secondary schools. To date, three independent cycles of SASS have been completed-1987-88, 1990-91, 1993-94. Unless otherwise indicated, the data I report here are from the 1993-94 SASS. Each cycle includes several sets of linked questionnaires: for each school sampled, for the principal or headmaster of each school, for the central district administration for each public school, and for a sample of teachers within each school. In addition, all those in the teacher sample who depart from their teaching jobs in the year subsequent to the survey are again contacted for the Teacher Follow-Up Survey (TFS) to obtain information on their departures. In each cycle, the effective sample sizes are about 5,000 school districts, 11,000 schools, and 55,000 teachers. For detailed discussions of the rationale, conceptualization, and design of SASS, see the original RAND Corporation design report by Haggstrom et al. (1988) or the more recent Ingersoll (1995b).

${ }^{2}$ I have written up detailed reports of my analyses on out-of-field teaching in three research reports published by NCES: Teacher Supply, Teacher Quality and Teacher Turnover (1995a), Out-of-Field Teaching and Educational Equality (1996a), The Status of Teaching As a Profession (1996b).

${ }^{3}$ Among these are What Matters Most: Teaching for America's Future (1996) and Doing What Matters Most: Investing in Quality Teaching (1997), both by the National Commission on Teaching and America's Future; "Quality Counts" (1998), a special supplement to Education Week; Education Watch (1996), by the Education Trust of the American Association for Higher Education.

${ }^{4}$ See, for example, Bobbitt and McMillen (1995); Smith, Young, Bae, Choy, and Alsalam, (1997, indicator 57); Bandeira de Mello and Broughman (1996). Note that each of these reports uses a slightly different definition of out-of-field teaching, and hence, the levels of outof-field teaching reported in each slightly vary.

${ }^{5}$ An example of where the SASS data on out-of-field assignments run counter to information obtained by school officials has arisen in the state of Maine. My research shows that high school teachers in Maine are often assigned to teach subjects for which they do not have certification. But as out-of-field assignments are prohibited by the Maine Department of Education, researchers in that state have simply denied that a problem exists and have concluded that the SASS data "do not present a true picture of Maine's teachers" (Townsend, Cobb, Moirs, \& McIntire, 1997, pp. 34-35, 71). For an excellent earlier report on the rules and regulations different states have concerning out-of-field assignments, see Robinson (1985).

${ }^{6}$ There is a large body of empirical research devoted to isolating and assessing the effects of various measures of teacher qualifications (e.g., education, training, experience) on student achievement. Although there are some inconsistent findings and considerable debate among researchers revolving around the methodological difficulties of statistically controlling for all the many factors affecting students' learning, in general, this research has found that subject knowledge and teaching skills are important predictors of both teaching quality and student learning (for reviews of this research, see Darling-Hammond \& Hudson, 1990; Ferguson, 1991; Hanushek, 1986; Hedges, Laine, \& Greenwald, 1994; Murnane \& Raizen, 1988; Shavelson, McDonnell, \& Oakes, 1989; for a recent empirical analysis using NELS:88, see Goldhaber \& Brewer, 1997).

${ }^{7}$ Detailed discussion of the characteristics, strengths, and limitations of a wide range of different measures of out-of-field teaching can be found in the methods and technical notes sections of my abovementioned research reports: Ingersoll (1995a, 1996a, 1996b). For an ex- cellent comparison of different measures of out-of-field teaching, see Bobbitt and McMillen (1995).

${ }^{8}$ See the Appendix for a chart showing my categorization of disciplines and subjects into fields of training and fields of teaching assignment.

${ }^{9}$ In Figure 1, regular certification refers to all those with regular, standard, full, advanced, or probationary certification. It does not include temporary, alternative, or provisional certificates. "Probationary" refers to the initial license issued after satisfying all requirements except completion of probationary period.

${ }^{10}$ In Tables 1 and 2, the estimates for life science, physical science, and history represent the percentage of teachers without at least a minor in those particular subfields. For example, in science, teachers (column 3) who hold a minor in any one of the sciences are defined as in field. On the other hand, for physical science-which includes physics, chemistry, space science, and geology-teachers (column 5) must hold a minor in one of those physical sciences to be defined as in field, rather than simply a minor in any science.

${ }^{11}$ Note that slight differences in the 1993-94 out-of-field teaching levels for public schools in Table 1 and Figure 2 are because the former includes grades 7-12 and the latter includes grades 9-12.

${ }^{12}$ In Table 1, "low poverty" refers to schools where $10 \%$ or fewer of the students receive publicly funded free or reduced-price lunches. "High poverty" refers to schools where more than $50 \%$ do so. Middle categories of school poverty are not shown.

${ }^{13}$ Note that in contrast to the Table 1 data showing the percent of teachers teaching out of field, the data in Table 2 show the percent of students being taught by out-of-field teachers. The data in Table 2 are from the 1990-91 SASS.

${ }^{14}$ The accuracy, necessity, and consequences of student ability grouping or tracking are, of course, among the most contentious issues in educational research and policy. Here I do not enter this debate, but simply use information on "type of class" provided by the teachers themselves to examine whether students in differently labeled classes receive more or less out-of-field teaching. I grouped eight "types" utilized in the questionnaire into three "tracks": low track-general, remedial, vocational, special education; medium track—academic/college preparatory; high track-honors, advanced placement, gifted. Given my crude method of categorization and the possible subjectivity of the teachers' classifications, the large differences across tracks are especially noteworthy.

${ }^{15}$ This viewpoint is especially common among news columnists. See, for example, the syndicated columns of David Broder, Thomas Sowell, and Maggie Gallagher the week of September 14-20, 1996.

${ }^{16}$ Most teachers have multiple degrees and, hence, have majors and minors in more than one subject or area. Table 3 takes account of all of the degrees that math teachers hold and shows teachers according to their major or minor that "best fits" math.

${ }^{17}$ A corollary explanation is the oft-repeated claim that high school sports and extracurricular activities are to blame for out-of-field teaching. In this view, principals are under pressure to hire candidates who are willing to coach, regardless of their academic qualifications, and also to provide part-time teaching assignments for those whose main job is physical education. Unfortunately, I have not been able to fully test this view because SASS has no data on coaches. But the data do show that teachers whose main field is physical education are not more likely than other kinds of teachers to be given outof-field assignments.

${ }^{18}$ In Figure 3, the data on the four academic fields refer to schools serving secondary students, the data for ESOL and special education refer to all schools, and the data on elementary positions refer to elementary schools. "Difficulty filling teaching vacancies" includes all those schools reporting either "somewhat difficult," "very difficult," or "could not fill" regarding filling vacancies for the current school year. The data in Figure 4 are from the 1990-91 SASS.

${ }^{19}$ Total turnover is composed of two components-attrition or those leaving the occupation altogether and migration or those who move from one teaching job to another. Traditionally, teacher supply-and-demand research has tended to focus solely on attrition and has ignored the migration component of total turnover because movers do not reduce the overall size of the teaching force and, hence, seem unrelated to shortages. But to school officials, on the ground it little matters whether a departing teacher is leaving the occupation altogether or simply moving to a teaching position in another school district. In either case, they create an opening that usually requires filling. In Figure 5, turnover refers to all those who moved from or left their teaching jobs in the 1994-95 year, except 
within-district transfers. Teachers could list up to three reasons for their departures. I categorized these as follows: school staffing action (reduction in force, layoff, school closing, reassignment); dissatisfaction (dissatisfied with teaching as a career or with school or with salary/benefits); family/personal (family move, pregnancy, childrearing, health); career (to pursue another career, to take courses to improve career opportunities, for better job); retirement. Retirement, of course, represents a larger portion ( $29 \%)$, but still not a majority of attrition alone.

${ }^{20}$ I have written detailed reports of my analyses on teacher turnover in one of the above-mentioned research reports published by NCES (Ingersoll, 1995a, chapter 3) and also in a research paper, Teacher Turnover: An Organizational Analysis (see Ingersoll, 1997).

${ }^{21}$ For a classic discussion of the semi-professional status of the teaching occupation, see Lortie (1969). For a recent empirical analysis, using SASS, of the degree of professionalization in schools, see Ingersoll (1996b).

\section{References}

Bandeira de Mello, V., \& Broughman, S. (1996). SASS by state. Washington, DC: U.S. Department of Education, National Center for Education Statistics.

Bobbitt, S., \& McMillen, M. (1995). Qualifications of the public school teacher workforce: 1988-1991. Washington, DC: U.S. Department of Education, National Center for Education Statistics.

Bryk, A., Lee, V., \& Smith, J. (1990). High school organization and its effects on teachers and students: An interpretive summary of the research. In W. H. Clune \& J. F. Witte (Eds.), Choice and control in American education: Vol. 1. The theory of choice and control in education (pp. 135-226). New York: Falmer Press.

Carey, C., \& Farris, E. (1994). Curricular differentiation in public high schools (NCES Report No. 95-360). Washington, DC: U.S. Department of Education, National Center for Education Statistics.

Chaney, B. (1994). The accuracy of teachers' self reports on their postsecondary education. Washington, DC: U.S. Department of Education, National Center for Education Statistics.

Conant, J. (1963). The education of American teachers. New York: McGrawHill.

Darling-Hammond, L. (1987). Teacher quality and equality. In P. Keating \& J. I. Goodlad (Eds.), Access to knowledge (pp. 237-258). New York: College Entrance Examination Board.

Darling-Hammond, L., \& Hudson, L. (1990). Pre-college science and mathematics teachers: Supply, demand and quality. In C. B. Cazden (Ed), Review of research in education (Vol. 16, pp. 223-264). Washington, DC: American Educational Research Association.

Education Trust. (1996). Education watch. Washington, DC: American Association for Higher Education.

Ferguson. R. (1991). Paying for public education: New evidence on how and why money matters. Harvard Journal on Legislation, 28, 465-498.

Glazer, N. (1987). Equity and excellence in our nation's schools. Harvard Educational Review, 57, 196-199.

Goldhaber, D., \& Brewer, D. (1997). Evaluating the effect of teacher degree level on educational performance. In W. Fowler (Ed.), Developments in school finance (pp. 199-208). Washington, DC: U.S. Department of Education, National Center for Education Statistics.

Haertel, E. (1991). New forms of teacher assessment. In G. Grant (Ed.), Review of research in education (Vol. 17, pp. 3-29). Washington, DC: American Educational Research Association.

Haggstrom, G. W., Darling-Hammond, L., \& Grissmer, D. (1988). Assessing teacher supply and demand. Santa Monica, CA: RAND Corporation.

Hanushek. E. (1986). The economics of schooling: Production and efficiency in public schools. Journal of Economic Literature, 24, 1141-1178.

Hedges, L., Laine, R., \& Greenwald, R. (1994). A meta-analysis of the effects of differential school inputs on student outcomes. Educational Researcher, 23(3), 5-14.
Ingersoll, R. (1993). Loosely coupled organizations revisited. Research in the Sociology of Organizations, 11, 81-112.

Ingersoll, R. (1995a). Teacher supply, teacher quality and teacher turnover. Washington, DC: National Center for Education Statistics.

Ingersoll, R. (1995b). An agenda for research on teachers and schools: Revisiting NCES'Schools and Staffing Survey. Washington, DC: National Center for Education Statistics.

Ingersoll, R. (1996a). Out-of-field teaching and educational equality. Washington, DC: National Center for Education Statistics.

Ingersoll, R. (1996b). The status of teaching as a profession. Washington, DC: National Center for Education Statistics.

Ingersoll, R. (1997, August). Teacher turnover: An organizational analysis. Paper presented at the annual meeting of the American Sociological Association, Toronto, Ontario, Canada.

Ingersoll, R. (in press). Teacher assessment and evaluation. In D. Levinson, P. Cookson, \& A. Sadovnik (Eds), Education and sociology: An encyclopedia. Washington, DC: Garland Press.

Kozol, J. (1991). Savage inequalities. New York: Harper-Collins.

Lortie, D. (1969). The balance of control and autonomy in elementary school teaching. In A. Etzioni (Ed), The semi-professions and their organizations: Teachers, nurses and social workers (pp. 1-53). New York: Free Press.

Murnane, R., \& Raizen, S. (Eds.). (1988). Improving indicators of the quality of science and mathematics education in grades $\mathrm{K}-12$. Washington, DC: National Academy Press.

Murnane, R., Singer, J., Willett. J., Kemple, J., \& Olsen, R. (Eds.). (1992). Who will teach?: Policies that matter. Cambridge, MA: Harvard University Press.

National Commission on Teaching and America's Future. (1996). What matters most: Teaching for America's future. New York: National Commission on Teaching and America's Future.

National Commission on Teaching and America's Future. (1997). Doing what matters most: Investing in quality teaching. New York: National Commission on Teaching and America's Future.

Oakes, J. (1990). Multiplying inequalities: The effects of race, social class, and tracking on opportunities to learn mathematics and science. Santa Monica, CA: RAND Corporation.

Quality counts: Public education in the 50 states [Special Supplement]. (1998, January 8). Education Week, 17(17), entire issue.

Robinson, V. (1985). Making do in the classroom: A report on the misassignment of teachers. Washington, DC: Council for Basic Education and American Federation of Teachers.

Shanker, A. (1985, October 27). Education's “dirty little secret. New York Times, section 4, p. E9.

Shavelson, R., McDonnell, L., \& Oakes, J. (1989). Indicators for monitoring mathematics and science education. Santa Monica, CA: RAND Corporation.

Shulman, L. (1986). Those who understand: Knowledge growth in teaching. Educational Researcher, 15(2), 4-14.

Smith, T., Young, B., Bae, Y., Choy, S., \& Alsalam, N. (1997). The condition of education. Washington, DC: U.S. Department of Education, National Center for Education Statistics.

Snyder, T., Hoffman, C., \& Geddes, C. (1997). The digest of education. Washington, DC: U.S. Department of Education, National Center for Education Statistics.

Toch, T. (1996, February 26). Why teachers don't teach: How teacher unions are wrecking our schools. U.S. News and World Report, pp. 62-71.

Townsend, R., Cobb, C., Moirs, K., \& McIntire, W. (1997). The status of teaching in Maine: A policy inventory. Orono: Education Policy Research Institute, University of Maine.

Tryneski, J. (1997). Requirements for certification of teachers, counselors, librarians, administrators for elementary and secondary schools. Chicago: University of Chicago Press.

Manuscript received November 13, 1997 Revision received June 30, 1998 Accepted July 7, 1998 